7. Ivanov, V.S .(1990). Fundamentals of Mathematical Statistics. Moscow: Physical Education and Sports. $175 \mathrm{p}$.

8. Kremer, N.Sh. (2000). Probability Theory and Mathematical Statistics. Moscow: Unity. 543 p.
9. Suslakov, B.A. (1982). Statistical methods of processing the results of measurements. Sports metrology. In prof. V.M. Zatsiorsky (Ed.). Moscow: Physical Education and Sports. 19-62.

\title{
DOLYNNYI Yuriy,
}

Ph.D in Pedagogy, Associate Professor,

Doctoral Student of Pedagogy and Methodology of Technological Education Department, Oleksandr Dovzhenko Hlukhiv National Pedagogical University

\author{
e-mail:mr.dya69@gmail.com
}

\section{STATISTICAL PROCESSING OF INDICATORS OF MOTIVATIONAL AND COGNITIVE COMPONENT OF READINESS OF FUTURE SPECIALISTS IN PHYSICAL EDUCATION TO REHABILITATION WORK WITH CHILDREN WITH LIMITED PHYSICAL POSSIBILITIES}

\begin{abstract}
Conceptual positions of professional preparation of future specialists on physical education and sport in relation to rehabilitation work with children with limit physical possibilities provide for : quality system of higher education, that answers the requirements of modern professional preparation of future specialists on physical education and sport to rehabilitation work; thorough knowledge by future specialists on physical education and sport of physiology and psychology-pedagogical features of children with physical limitations in development; perfection of state trade education, legislativelynormative base of Ukraine, creation of model of professional preparation of future specialists on physical education and sport to rehabilitation work with children with limit physical possibilities.

Quality system of higher education in direction of physical rehabilitation of people with limit physical possibilities considerably extends limits in methods, facilities and directions of rehabilitation. In collaboration with doctors and workers of social services specialists on physical therapy, ergo internists, physical rehabilitation mortgage bases of the national system of physical rehabilitation of people with limit physical possibilities.

Thorough knowledge by future specialists on physical therapy, ergo internists, the physical rehabilitation of physiology and psychology-pedagogical features of children with physical limitations in development needs foremost such knowledge: physician-biologist problems of children with physical limitations in development; basic anatomy-physiologist conformities to law of age-old devel-
\end{abstract}

opment of child; theoretical bases of medical sciences (of basis of general pathology, anatomy, biomechanics of sporting morphology, physiology, physic pathology, hygiene, clinic of internal illnesses, surgical and endocrine diseases, diseases and damages of locum thorium, reflex therapy, physiotherapy, python therapy, manual correction and massage); knowledge of the system and principles of physical rehabilitation; sanitary-hygienic requirements to the terms of realization of employments after a curative physical culture, massage, grant of physical therapy and manual procedures.

Perfection of state trade education is impossible without the co-ordinations actions of different state structures and departments, the task of that must be forming of strategy and tactics, organization and providing of measures of the physical internals of organism, increase of functional possibilities, strengthening of health of population sent to renewal, technical and skilled providing. These program development needs knowledge of features of organizationally-methodological approaches that must take into account the regional features of forming of modern society in different countries. Introduction of such programs is impossible without the adequate normativelylegal, technical and skilled providing.

Keywords: conception; preparation; specialists; physical rehabilitation; child; physical possibilities; physical education; professional preparation; limit.

Одержано редакиією 04.07.2018 Прийнято до публікаиї̈ 18.07.2018

DOI 10.31651/2524-2660-2018-14-34-40

ORCID 0000-0002-5947-314X

ІВАНИЦЬКА Оксана Степанівна,

провідний спеціаліст ректорату,

Національний університет " $\Lambda$ ьівська політехніка"

e-mail: kseniaivanytska@ukr.net

УДК 378

\section{ОСОБАИВОСТІ РЕФОРМУВАННЯ ВИЩОЇ ОСВІТИ У ЄВРОПІ В КОНТЕКСТІ СТУДЕНТОЦЕНТРОВАНОГО НАВЧАННЯ ТА РЕАМІЗАЦІї ТЬЮТОРСТВА I MEHTOPCTBA У $3 B 0$}

(ЗА MATEPIA AMИ KOHФEPEHЦIÏ: «REFORMING EUROPEAN HIGHER EDUCATION FROM POLICY TO PRACTICE», KYIV, JUNE, 08-09, 2018)

Дослідження відображає тендениї розвитку вищої освіти у Свропі, як результат реформування та розширення інтернаціоналізаиї $у$ ЗВО. В статті проаналізовано та систематизовано інформаиію, шо була представлена на конферениіï "Reforming European Higher Education - From Policy to Practice", яка відбулася у Kuєві, 8-9 червня, 2018 року. Дослідження містить аналітичний підсумок дискусій за участю українсъких та німеиьких науковиів, праиівників
Німецької служби академічних обмінів DAAD, Еразмус+ офрісу в Україні та представників Міністерства Освіти і Науки Украӥни. Підведено підсумки дискусій та представлено майбутні бачення. Стаття висвітлюе проблеми в реалізаиії реформ у Європі, зокрема в Німеччині та Україні та обговорення шляхів їх вирішення. В стані проаналізовані питання інтернаціоналізаиії, академічної мобільності, забезпечення якості у вищій освіті, визнання результатів 
навчання та забезпечення прозорості кожним 3BO.

ключові слова: реформування вищої освіти, забезпечення якості, програми обміну, академічна мобільність, стандарти і рекомендаиіï, інтернаиіоналізаиія.

Постановка пробцеми. Реформування вищої освіти $є$ одним з пріоритетних напрямків сьогодні нашої країни. Серед ключових показників реформування є забезпечення інтернаціоналізації у ЗВО, відповідно, розробленої стратегії інтернаціоналізації; забезпечення якості освіти через прозорість, студентоцентроване навчання, визнання результатів навчання; збільшення академічної мобіцьності. Дия належного впровадження реформ ми маємо орієнтуватися на Європейський досвід дмя узгодження відповідностей у сфері вищої освіти. Саме тому, проведення конференцій, семінарів, зустрічей 3 реформування вищої освіти $€$ надзвичайно важливими для обміну досвідом та узгодження подальших кроків щодо імплементації ряду реформ.

Мета статті - проаналізувати та систематизувати інформацію, представлену на конференції "Reforming European Higher Education - From Policy to Practiе", яка відбулася у Києві, 8-9 червня, 2018 року.

Викцад основного матеріалу досмідження. За останні роки була впроваджена низка реформ по всій Європі, як частина Болонського процесу [1]. Саме новий Закон про вищу освіту в Україні створив необхідні умови дмя проведення реформ у ЗВО [2]. Проте реформуванню у вищій освіті передувала низка проблем. "Поглиблення економічної кризи мало негативний вплив на автономію закладів та бюджет, особливо в південній, східній та центральній частинах Європи. Зростання безробіття серед молоді заставило Європейську Комісію переглянути свою політику щодо вищої освіти та зосередити увагу на співпраці між закладами вищої освіти та підприємствами дмя подальшого працевлаштування випускників" [1, с. 11].

Серед негативних тенденцій були демографічні зміни, старіння населення та низька народжуваність, що стало причиною для подальшого аналізу, оскіцьки це, в свою чергу, впливає на кількість майбутніх абітурієнтів. Разом з тим, позитивні зміни відбулися в концепції викладання, а саме з'явилися нові методики викладання. Велика увага почала приділятися отриманому досвідові в іншому ЗВО, часто в закордонному в рамках реалізації академічної мобільності та політики інтернаціоналізації. Якість викладання вже підтримується та контро$\Lambda$ ються процесами забезпечення якості, оцінюванням студентів та окремими віддімами. Серед стратегічних планів на майбутнє є наступні: забезпечення навчання впродовж життя (LLL - lifelong learning); студентоцентроване навчання та підготовка випускників до ринку праці; розвиток та впровадження ефективних стратегій інтернаціоналізації. Університети мають брати до уваги переваги, наслідки, ризики різних підходів, а також перспективи стабільності дмя забезпечення балансу між співпрацею та конкуренцією з іншими університетами. Також серед важливих чинників успішності ЗВО є розвиток викладачів та адміністративних працівників. Представники ЗВО розуміють важливість конкуренції та співпраці у вищій освіті, що впливає на рейтинговість ЗВО. Серед дослідження за 2015 рік студентська мобільність бума визнана опитаними як найважливіший фактор вдосконалення навчання та викладання. На думку представників різних ЗВО, процес визнання кредитів $є$ задовільним. На даний час інтернаціоналізація розвивається i така тенденція мише зростатиме $[1$, c. 30]. Як бачимо, разом 3 існуючими проблемами від економічної, демографічної кризи і до різких змін в суспільстві, за останні роки відбулися позитивні зміни та реформи у вищій освіті, що відповідає стратегіям забезпечення якості у вищій освіті.

«3 2005 року значний прогрес відбувся у забезпеченні якості освіти, визнанні результатів навчання, студентоцентрованого навчання та нових форм викладання" [3, с. 5].

Вища освіта, дослідження та інновації відіграють вирішальну роль в економічному рості та глобальній конкурентноспроможності. Вища освіта також $\epsilon$ необхідним елементом соціальноекономічного росту та культурного розвитку. Заклади вищої освіти ставлять перед собою різні завдання, включаючи розвиток та інтернаціоналізацію, цифрове навчання та нові форми викладання. 
Забезпечення якості освіти є важливим елементом при реагуванні на зміни, які можуть виникати в різних сферах. Варто зауважити, що стандарти забезпечення якості були подімені на 3 види: внутрішнє забезпечення якості, зовнішнє забезпечення якості, агенції забезпечення якості. Всі види разом утворюють Європейську систему забезпечення якості [3].

Надзвичайно важливо забезпечити всі необхідні умови навчання та надати підтримку дмя студентів дмя їхньої успішності в майбутньому, зокрема це стосується мобільних студентів. Роль викладача $є$ важливим елементом при підготовці студента та засвоєння ним знань. Заклади вищої освіти несуть відповідальність за якість та професійність своїх працівників, а також за забезпечення гідних умов праці та комфортної робочої атмосфери. Дия цього необхідно: встановити та дотримуватись чіткого та прозорого процесу працевлаштування і умов праці, що підкреслюють важливість викладання; пропонувати можливості та сприяти професійному розвитку викладачів; заохочувати до наукової діяльності для забезпечення необхідного балансу між освітнью та науковою роботою; заохочувати інновації в методиці викладання та використання новітніх технологій $[3$, c. 13)

Заклади вищої освіти мають забезпечити необхідні ресурси дмя допомоги студентам в навчальному процесі. Мова йде як про фізичні ресурси (бібліотеки, IT інфраструктуру) так і про мюдський фактор, a саме підтримку за допомогою тьюторів та порадників. Роль необхідного наставництва та підтримки $є$ особливо важливою при мобільності студентів. В цьому контексті роль допоміжного та адміністративного складу є надзвичайно важливою, саме тому, такі працівники мають бути кваліфікованими та мати можливості для розвитку компетенцій [3, c. 14].

Якщо говорити про розвиток вищої освіти у Європі з 2005 року, то основними змінами є перехід до студентоцентрованого навчання, визнання компетенцій, отриманих за межами формального навчання, поширення інтернаціоналізації вищої освіти, цифрове навчання, нові форми викладання. Все це впливає на забезпечення якості вищої освіти. Серед ключових показників якості $€$ також прозорість та довіра [4, с. 1].
Забезпечення якості у ЗВО має бути частиною його стратегічного менеджменту. Студенти є учасниками, які також несуть відповідальність за забезпечення якості $[4$, с. 3$]$.

ЗВО є відповідальні за те, що навчальний процес організований таким чином, щоб стимулювати студентів приймати активну участь в організації навчального процесу i за те, що оцінювання студентів відображає цей підхід [4, с. 7].

ЗВО мають публікувати інформацію про їхню діяльність, включаючи програми, яка має бути зрозумілою, точною, об'єктивною, актуальною та доступною. ЗВО також потрібно моніторити та періодично переглядати свої програми дия забезпечення цікей та потреб студентів і суспільства $[4$, с. 8].

Впровадження зовнішнього забезпечення якості має бути надійним, корисним, попередньо визначеним та поступово імплементованим. Воно включає самооцінювання, зовнішнє оцінювання, як правило, через відвідування сайту, звіт по внутрішньому оцінюванні, постійне спостереження [4, с. 11]. Зовнішнє забезпечення якості має виконуватися групою експертів, серед яких є студенти [4, c. 12].

Звіт експертів має бути опублікований та доступний дмя академічної спікьноти, зовнішніх партнерів та зацікавлених осіб. Якщо агенція приймає якесь формальне рішення на основі звітів, це рішення має бути опубліковане разом із звітом [4, с. 14).

Агенції мають керуватись правовою базою та мають бути визнані агенціями забезпечення якості компетентними органами державної вмади. Агенції мають бути незалежними та діяти автономно. Вони повністю відповідають за свої дії та результат цих дій без втручання третіх сторін [4, с. 17].

Агенції мають регулярно пубцікувати звіти, що включають аналіз та загальні висновки від організації зовнішнього забезпечення якості. Також агенції мають володіти необхідними фінансовими та своєї роботи [4, с. 18].

Дана тематика була широко висвітмена на конференції: "Reforming European Higher Education - From Policy to Practice", що проходила в Києві, 8-9 червня, 2018 року. Конференція була організова- 
на Німецькою Академічною Службою Обмінів DAAD. Серед співорганізаторів Національний Еразмус+ офріс в Україні та Міністерство Освіти і Науки України. Представником МОНУ був Ю. Рашкевич. Серед представників Еразмус + офрісу Світлана Шитікова, Іванна Атаманчук, Катерина Жданова.

Основні акценти:

- ЗВО мають забезпечувати якість вищої освіти (Quality Assurance). Система забезпечення якості має реалізовуватися на основі Європейських стандартів.

- Міжнародна діяльність має проводитися прозоро (transparency policy). В Києві та Брюсселі моніторять сайти ЗВО.

- Всі результати навчання здобуті закордоном в рамках академічної мобільності мають бути зараховані у ЗВО України. Наприклад, якщо мобільність не зараховується, університет-член програми Еразмус+ може звернутись в Брюссель, розірвати угоду та виставити рахунок університету, який не зараховує мобільність, за надання освітніх послуг.

- В Європі планують створити мобільні групи професіоналів у сфері вищої освіти (peer groups), які можна буде запросити до конкретного університету для роз'яснення незрозумілих питань та надання консультацій. Для того, щоб мобімьні групи були скеровані за призначенням, необхідно формувати певні запити в яких напрямках потрібні консультації.

- В кожному університеті має бути описана Стратегія розвитку університету ангАійською мовою.

- В Київському національному університеті імені Тараса Шевченка розробили найбільше положення про академічну мобільність, яке описує деталі мобільності та $є$ одним $з$ найдеталізованіших серед ЗВО в Україні [5]. Цей приклад варто було б наслідувати іншим університетам, оскільки поможення дуже відрізняються: в деяких ЗВО положення мітять Аише кАючові стратегії, в інших пункти про академічну доброчесність, розбудову мідерського потенціалу, стратегію співпраці з іншими ЗВО.

- Внутрішньоуніверситетська

політика має бути зосереджена над пошуком партнерів. Варто звернути увагу на попередні пункти для окреслення рекомендацій щодо співпраці 3 новими партнерами. Закордонні партнери від- даватимуть перевагу співпраці із ЗВО в яких чітко розроблене положення про академічну мобільність, діяльність відбувається прозоро, що підтверджується висвітленням інформації на сайті університету. Також важлива координація і співпраця між кафедрами кожного ЗВО.

На нашу думку, варто детальніше розглянути питання, що висвітлювалися на конференції, а саме перспективи щодо подальшого реформування вищої освіти та інтернаціоналізації у ЗВО України.

Серед основних напрямків, які можуть бути профінансовані європейськими грантами є підтримка інтернаціоналізації через оцифровування. Переведення інформації в цифрову форму $є$ надзвичайно важливим для ЗВО, що включає оцифровування наукових матеріалів, графіків, карт та бібліотечне оцифровування. Також важливим напрямком $\epsilon$ розширення співпраці українських ЗВО з європейськими партнерами, що передбачає зміцнення існуючої співпраці та пошук нових партнерів.

ДАя ЗВО сьогодні є надзвичайно важливим визначити реальний стан стратегії інтернаціоналізації у своєму ЗВО, або іï відсутність чи низький рівень. Серед негативних показників впровадження стратегії інтернаціоналізації є малий відсоток мобільності серед студентів, небажання обмінів серед викладачів, які бояться бути розкритикованими чи порівняними до своїх закордонних колег в зв'язку із застарілими методами викладання та відсутністю сучасних підходів і застосування інтернет-технологій.

Під час конференції були висвітлені основні тези Паризького комюніке [6].

Аналізуючи реалізовану роботу, міністри наголосили на ефективності командної роботи та спільного вирішення проблем. Було зазначено, що основними показниками розвитку у вищій освіті сьогодні $€$ академічна доброчесність, автономія ЗВО, можливість для студентів приймати участь у врядуванні університету. Серед результатів успішного реформування у вищій освіті є забезпечення якості у вищій освіті, як результат запровадження "Стандартів і рекомендацій щодо забезпечення якості в Європейському просторі вищої освіти" [7]. 
Запровадження програми Еразмус стало одним з основних кроків інтернаціоналізації у вищій освіті [8]. Програма $є$ надзвичайно важливою в кожній країні, зокрема в Україні, оскільки дає можливість реалізовувати академічну мобільність, що, в свою чергу, сприяє реформуванню вищої освіти та інтернаціоналізації у ЗВО. Як зазначають українські науковці: "У кожному із трьох циклів навчання у структурі ступеневих програм повинні бути створені сприятливі умови дмя кредитної та ступеневої внутрішньої і міжнародної мобільності" [9, с. 23]. Піс$\Lambda я$ закінчення програми Еразмус + буде продовження роботи в даному напрямку, а саме реалізація академічної мобільності, проте програма буде видозмінена [10].

Мобікьність студентів сприяє розвитку різноманіття. Саме тому, мають бути створені сприятливі умови для навчання студентів та забезпечений супровід у формі тьюторства та менторства під час навчального процесу. В українських реаміях ці функції, як правимо, виконуються координаторами та кураторами. Такий супровід $\epsilon$ необхідним для успішності студента, а відтак підготовки конкурентноспроможного працівника. Студентам необхідно чітко окреслити структуру навчального процесу, адже вони, зазвичай, звертають увагу на те, що їх пізніше будуть питати. Тому, на початку вивчення дисципліни студенти мають знати, як ї будуть оцінювати. Якщо говорити про мобільність студентів в гмобальному контексті, варто зазначити, що мобільність не має бути ціляю, а інструментом реалізації власного потенціалу та забезпечення якості вищої освіти.

Незважаючи на значні переваги мобільності студентів, існують також недоміки. Насамперед, це перспектива дмя студентів працевлаштовуватись в інших країнах, налагодивши контакти та знаючи іноземну мову. Саме тому, глобальним завданням країни є створення належних умов праці, гідної оплати праці та необхідної кількості робочих місць.

На конференції обговорили перспективи подальшої співпраці між європейськими ЗВО. Було зазначено, що існує тісна співпраця 3 німецькими університетами, що в значній мірі підтримується Німецькою службою академічних обмінів (DAAD). Як зазначили представники ску- жби, Україна сьогодні входить до однієї з найпріоритетніших країн до співпраці з німецькими ЗВО. Особливу увагу придіцятимуть мобільності студентів, оскільки вони успішно використовують нові знання в домашньому ЗВО та обмінюються знаннями з однолітками [11].

Питання довіри (trust) $€$ також на сьогодні одним з пріоритетних, оскільки довіра є одним з показників забезпечення якості [7]. Перш за все, йдеться про довіру між університетами - партнерами, на даний час це надзвичайно актуамьно в зв'язку з реалізацією академічної мобіцьності. Довіра потрібна при перезарахуванні результатів навчання. На сьогодні $є$ ще велика нерівність між освітянськими системами, тому довіра $\epsilon$ надзвичайно важливою дмя врегулювання робочих питань.

Оцифровування (digitalization) $\epsilon$ також на порядку денному обговорення реформування вищої освіти. Всі матеріа$\Lambda$ м мають бути в цифровій формі для зручності в роботі. Європейський студентський квиток має вирішити проблеми студентів, пов'язані з академічною мобіцьністю. Варто також зазначити про важливість Національної стратегії запровадження інформаційних технологій в навчанні. Німеччина має таку стратегію, цей досвід варто запозичувати, а також шукати джерела фінансування для іï впровадження [11].

Висновки. Реформування вищої освіти у Європі має безпосередній вплив на зміни, які відбуваються у вищій освіті України. Як показують аналітичні дослідження та твердження експертів, XXI століття характеризується позитивними зрушеннями в напрямку реалізації Бомонських принципів, розширення інтернаціоналізації у ЗВО, включаючи академічну мобільність [12]. Новий Закон «Про вищу освіту" в Україні надає більше автономії ЗВО та передбачає впровадження нових дидактичних принципів, створення нових напрямків і використання закордонних практик. Кцючові принципи, яких варто дотримуватися при реформуванні вищої освіти сьогодні є:

- забезпечення політики прозорості;

- централізована стратегія інтернаціоналізації університету; 
ності;

- збільшення академічної мобіль-

- забезпечення наставництва дмя студентів (тьюторства та менторства відповідно до закордонних практик);

- оцифровування; освіті.

- забезпечення якості у вищій

Надзвичайно важливим дмя представників українських ЗВО сьогодні є доступ до необхідної інформації та дискусії з експертами дмя швидкого реагування на виклики, які виникають сьогодні у вищій освіті. Саме тому, конференції та семінари, які організовуються Міністерством Освіти і Науки України, Еразмус+ офісом, Німецькою службою академічних обмінів DAAD та іншими освітніми інституціями $є$ актуальними.

\section{Список бібліографічних посимань}

1. Sursock, A. (2015). Trends 2015: Learning and Teaching in European Universities. Brussels: European University Association. $128 \mathrm{p}$.

2. Закон України "Про вищу освіту" № 2443-VIII (редакція від 25.07.2018). URL: http://zakon.rada.gov.ua/laws/show/1556-18.

3. Standards and Guidelines for Quality Assurance in the European Higher Education Area (ESG). K.: CS Ltd., 2015. 32p.

4. Comparative analysis of the ESG 2015 and ESG 2005, 20 p. Retrieved from: http://www.equipproject.eu/wp-

content/uploads/EQUIP_comparative-analysis-ESG2015-ESG-2005.pdf

5. Віддік академічної мобільності Київського Національного Університету імені Тараса Шевченка. URL: http: / / mobility.univ.kiev.ua.

6. EHEA Ministerial Conference Paris 2018. Retrieved from: http://www.ehea2018.paris /

7. Paris Communique. Retrieved from: https://mon.gov.ua/storage/app/media/news/Нов ини/2018/06/06/12/paris-

communiqueenua2018.pdf

8. Рашкевич Ю. М. Болонський процес та нова парадигма вищої освіти України: монографія. Аьвів: Видавництво Аьвівської помітехніки, 2014. 168 с.

9. Бобамо Ю., Павлиш В., Загородній А., Бабин I. (2014). Запровадження та використання болонсь- ких інструментів прозорості в європейському просторі вищої освіти. Вища школа: науковопрактичне видання. 2014. №1 (115). С. 19-31.

10. Програма Еразмус +. http:/ / erasmusplus.org.ua/

11. Німецька служба академічних обмінів DAAD (Deutscher Akademischer Austauschdienst). URL: https://www.daad-ukraine.org/uk/

12. Білоцерківська Н. Г. Реформування вищої освіти в Україні: правові аспекти. Форум права. 2014. №4. C. 13-17. URL: http://nbuv.gov.ua/UJRN/FP_index.htm_2014_4_4. References

1. Sursock, A. (2015). Trends 2015: Learning and Teaching in European Universities. Brussels: European University Association. 128 p.

2. Law of Ukraine "On higher education" (2014) No. 2443-VIII (as amended on July 25, 2018). Retrieved from: http://zakon.rada.gov.ua/laws/show/155618.

3. 3 Standards and Guidelines for Quality Assurance in the European Higher Education Area (ESG) (2015). K.: CS Ltd. 32p.

4. Comparative analysis of the ESG 2015 and ESG 2005, 20 p. Retrieved from: http://www.equipproject.eu/wp-

content/uploads/EQUIP_comparative-analysis-ESG2015-ESG-2005.pdf

5. Academic Mobility Office of Taras Shevchenko National university of Kyiv. Retrieved from: http: / / mobility.univ.kiev.ua

6. EHEA Ministerial Conference Paris 2018. Retrieved from: http: / / www.ehea2018.paris /

7. Paris Communique. Retrieved from: https://mon.gov.ua/storage/app/media/news/Нов ини /2018/06/06/12/paris-

communiqueenua2018.pdf

8. Rashkevych, Yu.M. (2014). The Bologna Process and the new paradigm of higher education in Ukraine: a monograph. Lviv: Publishing House of Lviv Polytechnic. $168 \mathrm{p}$.

9. Bobalo, Yu., Pavlysh V., Zagorodniy A., Babyn I. (2014). Implementation and use of the Bologna transparency instruments in the European Higher Education Area. Higher school: scientific and practical edition. 1 (115). 19-31.

10. Erasmus + programme. Retrieved from: http:/ / erasmusplus.org.ua/

11. German Academic Exchange Service DAAD (Deutscher Akademischer Austauschdienst). Retrieved from: https://www.daad-ukraine.org/uk/

12. Bilocerkivska, N. H. (2014). Reforming of the higher education in Ukraine: legal aspects. Forum of law. 4. 13-17. Retrieved from: http://nbuv.gov.ua/UJRN/FP_index.htm_2014_4_4.

IVANYTSKA Oksana,

Leading Specialist of the Rectorate,

Lviv Polytechnic National University

e-mail: kseniaivanytska@ukr.net

\section{SPECIFIC FEATURES OF HIGHER EDUCATION REFORMING IN EUROPE IN THE CONTEXT OF STUDENT-CENTERED TEACHINGING AND REALIZATION OF TUTORING AND MENTORING IN ESTABLISHMENTS OF HIGHER EDUCATION (a Study of the Conference Materials: "Reforming European Higher Education - From Policy to Practice", Kyiv, June, 08-09, 2018")}

Abstract. The research reflects trends in the development of higher education in Europe, as a result of reforming and internationalization expanding at HEEs. The article analyzes and systematizes the information that was presented at the conference "Reforming European Higher Education - From Policy to Practice", which took place in Kyiv, June 8-9, 2018. The research contains an analytical summary of discussions among Ukrainian and German scientists, employees of the German Academic
Exchange Service DAAD, Erasmus + Office in Ukraine and representatives of the Ministry of Education and Science of Ukraine. The discussions are summarized and the future vision is presented. The article highlights problems in reforms implementation in Europe, in particular in Germany and Ukraine, as well as possibilities to solve them. The issues of internationalization, academic mobility, quality assurance in higher education, recognition of learning outcomes and transparency of each HEEs are 
provided in the article. The paper also includes critical analyzis of the internationalization strategies of different HEEs as well as the recommendations concerning its improvement. It is provided that issues on higher education reforming are discussed during numerous meetings, roundtables, seminars, conferences, etc. one of the latest events was the Paris Communique. There was the possibility in Paris for the Ministers to discuss the latest tendencies and challenges in higher education. The conference "Reforming European Higher Education - From Policy to Practice" made it possible to provide ideas of experts in higher education to the interested representatives from different HEEs. This, in turn, is a good platform for knowledge transfer and ideas exchange.

Keywords: higher education reforming; quality assurance; exchange programmes; academic mobility; standards and guidelines; internationalization.

Одержано редакиією 29.09.2018 Прийнято до публікаиії 08.10.2018

DOI 10.31651/2524-2660-2018-14-40-45

ORCID 0000-0002-1029-7843

\section{МИСЕНКО ОАександра Микомаївна,}

кандидат філологічних наук, доцент кафедри теорії та методики дошкільної і спеціальної освіти педагогічного факультету, Прикарпатський національний університет імені Василя Стефаника e-mail: lysenkowa@gmail.com

\section{ЦІННІСНІ ОРІСНТАЦІЇ ОСОБИСТОСТІ МАЙБУТНЬОГО ПЕДАГОГА: ТЕОРЕТИЧНИЙ АНААІЗ ДОСАІДЖЕННЯ ПРОБАЕМИ}

У статті проаналізовано поняття иінностей та иіннісних орієнтаиій майбутнього педагога. Наголошено на зміні суспільних иінностей.

Виокремлено три фрорми існування иінностей. Наголошено, шуо лише иіннісно сорормована особистість майбутнього педагога здатна всебічно розвивати dimeй.

Ключові слова: ијннісні орієнтації; майбутній педагог; иінність; вихователі.

Постановка пробцеми: в останні два десятиліття йде активна переоцінка цінностей i, відповідно, ціннісна переорієнтація громадян України. Переважаючими стають орієнтація на матеріальні цінності і руйнація національної ідеї. Однак саме постановка життєвих цілей i структурна організація життєвих цінностей є найбільш важливим завданням дмя особистості.

Мета статті: розглянути та обгрунтувати ціннісні орієнтації, як найважливіші елементи внутрішньої структури особистості, закріплені життєвим досвідом індивіда, всією сукупністю його переживань і відмежовує значуще, істотне дмя даної мюдини від незначного, несуттєвого.

Виклад основного матеріалу: сукупність сформованих, усталених ціннісних орієнтацій виступає до певної міри віссю свідомості, яка забезпечує стійкість особистості, спадкоємність певного типу поведінки і діяльності, виражену в спрямованості потреб та інтересів.

В силу цього ціннісні орієнтації виступають найважливішим фактором, що регулює та детермінує мотивацію особистості [1]. Основний зміст ціннісних орієнтацій - це політичні, філософські (сві-

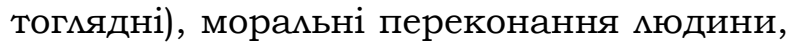
гАибокі і постійні прихильності, моральні принципи поведінки. Тому у будь-якому суспільстві ціннісні орієнтації особистості є об'єктом виховання, цілеспрямованого впливу. Ціннісні орієнтації діють як на рівні свідомості, так і на рівні підсвідомості, визначаючи спрямованість вольових зусиль, уваги, інтелекту. Механізм дії і розвитку ціннісних орієнтацій пов'язаний з необхідністю вирішення протиріч і конфміктів у мотиваційній сфері, селекції прагнень особистості, що виражається у боротьбі між обов'язком і бажанням, мотивами морального та утилітарного порядку [2].

На думку, М. Яницького, розвинені ціннісні орієнтації - ознака зрілості особистості, показник міри іiі соціальності. Це призма сприйняття не тільки зовнішнього, але і внутрішнього світу індивіда, яка обумовлює зв'язок між свідомістю і самосвідомістю, психологічне підгрунтя для вирішення в індивідуальному плані питання про сенс життя, завдяки якому відбувається інтеграція сукупності ціннісних орієнтацій в щось цікісне і своєрідне, характерне саме дия даної особистосTi [3].

Г. Сунгатумліна вважає, що стійка i несуперечлива сукупність ціннісних орієнтацій обумовлює такі якості особистості, як цілісність, надійність, вірність пев- 